\title{
PERANAN OSIS DALAM MEMBENTUK KARAKTER PEDULI SOSIAL SISWA DI SMA NEGERI 3 BARRU
}

\author{
Oleh: Yusmuliadi ${ }^{1}$, Andi Agustang ${ }^{2}$ \\ ${ }^{12}$ Program Studi pendidikan Sosiologi Fakultas Ilmu Sosial dan Hukum \\ Universitas Negeri Makassar \\ Email: yusmuliadi3112@gmail.com 1, andi.agustang@unm.ac.id².
}

\begin{abstract}
Abstrak
Penelitian ini bertujuan untuk mengetahui peranan OSIS dalam membentuk karakter peduli sosial siswa di SMA Negeri 3 Barru dan untuk mengetahui hambatan OSIS dalam membentuk karakter peduli sosial siswa di SMA Negeri 3 Barru. Jumlah informan pada penelitian ini sebanyak 18 orang yang ditentukan melalui teknik purposive sampling dengan kriteria kepala sekolah, wakil kepala sekolah bidang kesiswaan, pembina OSIS, pengurus aktif OSIS dan siswa yang bukan pengurus OSIS. Teknik pengumpulan data yang dilakukan yaitu observasi, wawancara, dan dokumentasi. Teknik analisis data kualitatif tipe deskriptif melalui tiga tahap yaitu reduksi data, penyajian data, dan penarikan kesimpulan. Teknik pengabsahan data menggunakan triangulasi sumber. Hasil penelitian menunjukkan bahwa peranan OSIS dalam membentuk karakter peduli sosial siswa di SMA Negeri 3 Barru yaitu dengan membuat dan melaksanakan program kerja berbasis kegiatan sosial, menggerakkan atau memotivasi siswa pada kegiatan sosial, dan mencegah terjadinya penyimpangan di sekolah. Hambatan OSIS dalam membentuk karakter peduli sosial siswa di SMA Negeri 3 Barru yaitu kurangnya kesadaran sosial siswa, egoisme etis siswa, pengaruh lingkungan luar sekolah, dan kondisi ekonomi siswa.
\end{abstract}

Kata Kunci: Peranan OSIS, karakter, peduli sosial.

\section{PENDAHULUAN}

Pendidikan karakter sangat penting diberikan kepada peserta didik saat ini mengingat berbagai pengaruh negatif dari media sosial dan lingkungan menimbulkan berbagai penyimpangan di sekolah. Penyimpangan tersebut disebabkan oleh siswa itu sendiri. Salah satu penyimpangan yang sering terdengar di media adalah kasus siswa yang memukuli gurunya. Oleh karena itu, pemerintah saat ini menggalakkan pendidikan karakter di sekolah. Dengan pemberian pendidikan karakter kepada peserta didik, akan membentuk anak yang siap untuk menghadapi tantangan dari luar (Ramlafatma et al., 2021).

Sebagai tenaga pendidik, seorang guru diharapkan mampu untuk menerapkan pendidikan karakter pada setiap mata pelajaran untuk mencapai tujuan pendidikan nasional. Namun karena minimnya jam pelajaran khususnya mata pelajaran pendidikan kewarganegaraan dan pendidikan agama yang pada dasarnya untuk membentuk karakter menyebabkan peserta didik menganggap remeh mata pelajaran 
tersebut. Apalagi jika guru yang mengampu mata pelajaran tersebut kurang kreatif dalam mengelola kelas. Masih ada guru yang menggunakan metode ceramah, menghafal atau sekedar mencatat dalam proses pembelajaran yang akan membuat peserta didik merasa jenuh bahkan tertidur dalam kelas. Secara tidak langsung pendidikan yang seperti ini telah membunuh karakter anak bangsa menjadi tidak kreatif (Rosita, 2018).

Tenaga pendidik harus mampu merubah pendidikan sekarang menjadi pendidikan yang bermutu, tidak hanya mengedepankan aspek kognitif saja tetapi juga harus memperhatikan aspek afektif dan psikomotoriknya. Jika pendidik mampu menyeimbangkan ketiga aspek tersebut maka pendidikan bisa menumbuhkan jiwa yang berkarakter tinggi dan berwawasan luas (Tutuk, 2015). Pendidikan karakter tidak hanya didapatkan melalui kegiatan intrakurikuler atau proses pembelajaran formal di dalam kelas. Akan tetapi juga dapat terwujud melalui kegiatan ekstrakurikuler atau kegiatan luar kelas misalnya dengan keterlibatan peserta didik dalam kegiatan OSIS.

Selain kepala sekolah dan guru, OSIS juga memiliki peran dan tanggung jawab dalam pembentukan karakter siswa di sekolah. Pengurus OSIS dalam menjalankan tugas didampingi oleh pembina dan kepala sekolah yang bertugas sebagai penanggung jawab utama dalam kegiatan OSIS. Salah satu bentuk perhatian pemerintah dalam usaha kegiatan pengembangan pendidikan karakter di sekolah dengan dikeluarkannya Permendiknas Nomor 39 Tahun 2008 tentang pembinaan kesiswaan yang menyatakan bahwa "Organisasi kesiswaan di sekolah berbentuk Organisasi Siswa Intra Sekolah (OSIS)”(Pembinaan Kesiswaan, 2008).

Dari uraian di atas maka sekolah perlu dan wajib menyelenggarakan pembinaan kesiswaan dengan memberi bekal dan kemampuan kepada peserta didik untuk mengembangkan potensi peserta didik melalui organisasi ekstrakurikuler di sekolah. Di dalam suatu organisasi peserta didik akan belajar bersosialisasi dengan sesama karena sejatinya manusia sebagai makhluk sosial tidak bisa hidup sendiri melainkan membutuhkan orang lain.

Kegiatan ekstrakurikuler dilakukan melalui berbagai kegiatan positif dapat membentuk karakter siswa dalam pelaksanaan program kerja yang telah direncanakan sebelumnya. Berbagai kegiatan tersebut diorientasikan terutama untuk penanaman dan pembentukan sikap, perilaku dan kepribadian peserta didik agar menjadi manusia yang berkarakter. Kegiatan ekstrakurikuler yang selama ini diselenggarakan sekolah merupakan salah satu media yang potensial untuk pembinaan karakter dan peningkatan mutu akademik peserta didik. Kegiatan ekstrakurikuler diselenggarakan oleh pendidik dan atau tenaga kependidikan yang berkemampuan serta berwenang di sekolah.

SMA Negeri 3 Barru merupakan salah satu sekolah di kabupaten Barru yang mengembangkan karakter pada kegiatan ekstrakurikuler dengan melibatkan siswa terlibat aktif pada berbagai kegiatan ekstrakurikuler salah satunya adalah OSIS. Dengan keterlibatan siswa di OSIS diharapkan dapat membantu sekolah dalam pelaksanaan 
kegiatan sekolah khususnya di bidang kesiswaan dan diharapkan dapat membantu sekolah membentuk karakter siswa di luar jam pelajaran.

Pengurus OSIS SMA Negeri 3 Barru menyusun program kerja yang diorientasikan pada pembentukan karakter siswa. Penyusunan program kerja OSIS dilaksanakan dalam forum yang diberi nama rapat kerja dihadiri oleh pengurus baru dan pembina OSIS sebagai pengarah agar menghasilkan program kerja yang baik. Dalam merencanakan program kerja, OSIS memiliki maksud dan tujuan yaitu membentuk karakter siswa. Jika program kerja tersebut terlaksana dengan baik dan tepat sasaran, maka peran OSIS sebagai organisasi di sekolah untuk membentuk karakter dapat tercapai. Tentunya keberadaan OSIS di SMA Negeri 3 Barru sangat membantu sekolah dalam pembentukan karakter dan meningkatkan prestasi siswa.

Hampir sama dengan beberapa sekolah yang ada di Indonesia, SMA Negeri 3 Barru mengalami berbagai masalah pada siswa terkait dengan karakternya. Berbagai permasalahan tersebut seperti pelanggaran tata tertib, menongkrong di warung luar sekolah pada saat masih jam sekolah, menyontek, merokok, bolos, atau bullying. Berbagai permasalahan yang terjadi diatas dilakukan oleh siswa bahkan beberapa diantaranya pengurus OSIS itu sendiri. Tidak hanya itu, timbul juga masalah pada siswa yang ikut OSIS hanya sekedar ikut teman atau sekedar mencari perhatian agar lebih dikenal oleh junior maupun siswa lainnya. Selain itu, terkadang pada saat diadakan rapat kegiatan OSIS masih ditemui beberapa anggota yang tidak menghadiri rapat.

Pengurus OSIS yang seharusnya menjadi contoh bagi siswa lain tidak sepantasnya melakukan pelanggaran tersebut. Seharusnya pengurus OSIS tidak boleh hanya sekedar ikut-ikutan karena dalam kegiatan OSIS diperlukan keseriusan dan keaktifan dari siswa agar siswa benar-benar belajar dalam berorganisasi.

Namun ada juga pengurus OSIS yang terlalu fokus pada organisasi sehingga melupakan kewajiban utamanya sebagai siswa yaitu belajar. Jika memilih ikut organisasi seharusnya siswa bisa mengatur waktu untuk belajar dan berorganisasi. Sehingga kecerdasan intelektual dan kecerdasan emosional seimbang tanpa melupakan kecerdasan spiritual (Rohmah, 2018).

Menjadi pengurus OSIS bukanlah sesuatu yang mudah. Pengurus OSIS memiliki peran dan tanggung jawab yang telah diamanahkan oleh sekolah. Harus memiliki kesadaran dan kepedulian kepada sesama siswa maupun masyarakat yang membutuhkan. Keterlibatan siswa dalam OSIS diharapkan dapat memberikan dampak yang besar yaitu mencetak siswa yang memiliki karakter terpuji dan diharapkan dapat meminimalkan penyimpangan yang banyak dilakukan siswa. Bukan malah ikut terlibat dalam penyimpangan tersebut.

\section{METODE PENELITIAN}

Jenis penelitian ini adalah kualitatif dengan pendekatan deskriptif. Dalam penelitian ini penulis mengambil lokasi di SMA Negeri 3 Barru. Adapun tahap-tahap penelitian yang dilakukan dalam penelitian ini secara garis besar yaitu tahap pra 
penelitian, tahap penelitian, dan tahap akhir. Sumber data yang digunakan yaitu sumber data primer dan sumber data sekunder. Jumlah informan sebanyak 18 orang yang dipilih menggunakan teknik purposive sampling. Teknik pengumpulan data dengan metode observasi, wawancara, dan dokumentasi. Pengecekan keabsahan data dilakukan melalui triangulasi sumber. Teknik analisis data meliputi reduksi data, penyajian data, dan penarikan kesimpulan (Agustang, 2021).

\section{PEMBAHASAN}

\section{Peranan OSIS dalam Membentuk Karakter Peduli Sosial Siswa di SMA Negeri 3 Barru}

Pembahasan ini mengenai peranan OSIS dalam membentuk karakter peduli sosial siswa di SMA Negeri 3 Barru. Berdasarkan hasil penelitian yang telah dilakukan, penulis menemukan bahwa peran OSIS SMA Negeri 3 Barru yaitu membuat dan melaksanakan program kerja berbasis kegiatan sosial, penggerak/motivator bagi siswa pada kegiatan sosial, dan mencegah terjadinya penyimpangan di sekolah.

Peran OSIS dalam membentuk karakter peduli sosial siswa yang pertama yaitu membuat dan melaksanakan program kerja berbasis kegiatan sosial. OSIS merupakan salah satu organisasi di sekolah tingkat menengah yang mewadahi siswa dalam hal pengembangan minat dan bakat siswa. "Kegiatan ekstrakurikuler pada hakikatnya bukan hanya untuk menampung dan tempat untuk menyalurkan kompetensi, minat dan bakat peserta didik tetapi lebih jauh bahwa kegiatan ekstrakurikuler mampu menjadi bagian yang tidak terpisahkan dalam usaha membentuk karakter peserta didik sebab pada kegiatan ekstrakurikuler terjadi juga interaksi antar sesama...." (Ningsih, 2015, hlm. 147). OSIS sebagai salah satu kegiatan ekstrakurikuler tidak hanya sebagai tempat untuk menyalurkan kompetensi, minat dan bakat siswa, akan tetapi OSIS juga mampu membentuk karakter siswa.

OSIS menampung dan menyalurkan aspirasi siswa serta pembinaan dan pengembangan potensi diri siswa dalam berbagai bidang seperti keagamaan, pembinaan budi pekerti dan akhlak mulia, wawasan kebangsaan dan bela negara, keolahragaan, keterampilan dan kewirausahaan, kesenian, teknologi informasi dan komunikasi, serta pembinaan bahasa Inggris.

Pada struktur pengurus OSIS terdapat bidang pembinaan demokrasi, HAM, pendidikan politik, lingkungan hidup, kepekaan toleransi sosial dalam konteks masyarakat plural. Fungsi bidang ini untuk mengembangkan peran siswa di dalam OSIS sesuai tugas masing-masing, melaksanakan latihan kepemimpinan siswa, melaksanakan kewajiban dan hak sendiri serta orang lain dalam pergaulan masyarakat, melaksanakan kegiatan orientasi siswa baru yang bersifat akademik dan pengenalan lingkungan tanpa kekerasan, serta melaksanakan penghijauan dan perindangan lingkungan sekolah. Pada bidang inilah sebagian besar pembentukan karakter peduli sosial siswa dilakukan.

Selain dari fungsi tersebut, OSIS telah membuat dan menyusun program kerja berbasis kegiatan sosial seperti bakti sosial, gerakan saudara asuh, dan pembagian takjil 
pada bulan ramadhan. Bakti sosial merupakan program kerja yang bertujuan untuk meningkatkan solidaritas, kepedulian, rasa tanggung jawab, dan kesadaran atas kebersihan lingkungan. Sasaran dari kegiatan ini adalah sekolah dan melibatkan seluruh warga sekolah. Selain itu, bakti sosial ini juga dilaksanakan melalui bantuan kepada masyarakat korban bencana, seperti tsunami di Palu tahun 2018 dan banjir bandang di Masamba tahun 2020. Bantuan yang diberikan berupa pengumpulan dana, pakaian layak pakai, dan beras.

Kemudian gerakan saudara asuh merupakan program kerja yang bertujuan untuk menumbuhkan rasa kepedulian terhadap sesama. Pelaksanaan program kerja ini dilakukan dengan mengumpulkan dana atau barang yang akan diberikan kepada siswa yang terkena musibah, seperti berduka atau terkena bencana. Sedangkan program kerja bagi-bagi takjil dilakukan pada bulan ramadhan. Program kerja ini bertujuan untuk menumbuhkan kecintaan bulan suci ramadhan dan meningkatkan kepekaan serta kepedulian sosial.

Penyusunan program kerja tersebut bertujuan untuk membentuk karakter peduli sosial siswa. Tidak hanya direncanakan, akan tetapi OSIS juga melaksanakan program kerja tersebut sebagai bentuk tanggung jawab pengurus dan untuk mencapai tujuan yang ingin dicapai.

Hasil penelitian menunjukkan bahwa OSIS SMA Negeri 3 Barru sebagai organisasi di sekolah telah menjalankan perannya dengan membuat dan melaksanakan program kerja khususnya kegiatan sosial. Terkait dengan pembentukan karakter peduli sosial, OSIS mewadahi minat dan bakat siswa dalam berbagai bidang termasuk peduli terhadap sesama. Selain itu, OSIS juga membekali siswa dengan melakukan kegiatan bersama, bertukar pikiran, mengeluarkan pendapat, melatih jiwa kepemimpinan siswa, dan mengajak siswa untuk lebih peka dengan keadaan sekitar. Hal ini sesuai dengan pendapat Supriatna (2010, hlm. 16) bahwa "OSIS dalam mewujudkan fungsinya sebagai wadah harus melakukan upaya-upaya bersama-sama dengan jalur yang lain, misalnya latihan kepemimpinan siswa yang bersifat ekstrakurikuler."

Peran OSIS dalam membentuk karakter peduli sosial yang kedua adalah sebagai penggerak/motivator bagi siswa pada kegiatan sosial. OSIS merupakan organisasi induk di sekolah menengah. Oleh karena itu, OSIS harus mampu menjadi contoh bagi siswa di sekolah.

OSIS sebagai penggerak/motivator artinya mampu mempengaruhi siswa untuk berbuat dan melakukan kegiatan bersama-sama dalam mencapai tujuan. Motivasi adalah suatu perangsang dan dorongan bagi seseorang agar dapat melakukan sesuatu yang lebih baik dan produktif. Sedangkan motivator adalah orang yang melakukan suatu dorongan tersebut.

Dalam hal pembentukan karakter peduli sosial, OSIS menjadi penggerak siswa di sekolah untuk mengikuti kegiatan sosial yang memiliki manfaat bagi sesama. Tidak hanya dalam lingkungan sekolah, tetapi juga lingkungan luar sekolah (masyarakat luas). Tanpa menunggu perintah atau komando dari pembina, OSIS SMA Negeri 3 Barru 
mengadakan penggalangan dana atau pengumpulan barang yang dibutuhkan bagi masyarakat yang berduka atau terkena dampak bencana.

Kegiatan sosial yang dimaksud adalah kegiatan yang dilakukan diluar dari program kerja yang telah direncanakan oleh pengurus OSIS. Kegiatan tersebut seperti donor darah yang dilakukan oleh sekolah, melakukan penggalangan dan pengumpulan dana atau barang yang dibutuhkan, dan peduli kepada sesama, baik dalam lingkungan sekolah atau lingkungan masyarakat.

Pada pelaksanaan donor darah yang dilakukan oleh sekolah, pengurus OSIS membantu pihak sekolah dengan menggerakkan siswa untuk ikut berpartisipasi donor darah. Antusias siswa untuk ikut donor darah cukup banyak. Namun, tidak semua siswa bisa ikut donor darah karena pendonor harus sesuai dengan persyaratan ikut donor darah. Selain itu, program donor darah ini hanya dilaksanakan sekali dalam tiga bulan.

Hasil penelitian menunjukkan bahwa OSIS SMA Negeri 3 Barru telah menjalankan perannya sebagai penggerak/motivator bagi siswa pada kegiatan sosial. Cara pemberian motivasi yang diberikan oleh OSIS kepada siswa adalah dengan memberikan pemahaman kepada siswa untuk memposisikan diri kepada orang yang sedang berduka atau terkena musibah. Selain itu, OSIS juga menggerakkan siswa ketika ada kegiatan sosial, baik yang telah diprogamkan oleh OSIS maupun sekolah.

Peran OSIS dalam pembentukan karakter peduli sosial yang ketiga adalah mencegah terjadinya penyimpangan di sekolah. Dengan mengajak siswa untuk melakukan kegiatan yang positif dan bermanfaat, maka penyimpangan yang terjadi di sekolah dapat berkurang bahkan hilang. Peran ini dapat terlaksana dengan baik apabila peran OSIS sebagai motivator terlaksana terlebih dahulu.

Hasil penelitian menunjukkan bahwa OSIS menjalankan perannya untuk mencegah terjadinya penyimpangan di sekolah. Hal ini dapat dilihat dari usaha OSIS untuk mengajak siswa terlibat langsung dalam menjalankan program kerja OSIS seperti bakti sosial, gerakan saudara asuh, peringatan hari-hari besar, dan beberapa kegiatan lainnya untuk membentuk karakter peduli sosial siswa, baik yang telah direncanakan maupun tidak direncanakan oleh pengurus OSIS.

Jika dilihat karakteristik kepedulian menurut Yaumi (2014, hlm. 78), OSIS SMA Negeri 3 Barru telah menunjukkan karakteristik tersebut. Karakteristik yang pertama yaitu berupaya untuk menjaga kebaikan bersama orang lain. Hal ini dilihat dari kepekaan pengurus OSIS untuk berbagi kepada sesama yang membutuhkan. Karakteristik kedua yaitu memiliki jiwa yang penuh kasih dan peduli. Hal ini dapat dilihat dari kepedulian pengurus OSIS yang memiliki empati lebih.

Karakteristik ketiga yaitu mengekspresikan rasa syukur. Hal ini dapat dilihat dari kegiatan OSIS dalam memperingati hari-hari besar dan menyisihkan uangnya untuk membantu teman yang membutuhkan. Karakteristik terakhir yang tampak adalah membantu orang yang membutuhkan. Hal ini dilihat dari inisiatif pengurus OSIS dan siswa untuk ikut donor darah dan mengumpulkan dana atau barang yang akan diberikan kepada orang yang membutuhkan. 
Terkait dengan teori yang dipakai dalam penelitian ini yaitu teori peran yang menyatakan bahwa seseorang dikatakan berperan jika melaksanakan hak dan kewajibannya sesuai dengan kedudukannya. Jika dilihat dari pembahasan diatas, OSIS memiliki kedudukan di sekolah dan telah melaksanakan hak dan kewajibannya dengan membuat dan melaksanakan program kerja berbasis kegiatan sosial, menggerakkan atau memotivasi siswa pada kegiatan sosial, dan mencegah terjadinya penyimpangan di sekolah sehingga OSIS SMA Negeri 3 Barru dapat dikatakan berperan dalam pembentukan karakter peduli sosial siswa.

Kemudian terkait dengan penelitian terdahulu, penelitian ini sama dengan penelitian yang dilakukan oleh Nursanti(2013, hlm. vii) dengan judul "Peranan Organisasi Siswa Intra Sekolah dalam membentuk karakter siswa SMP Negeri di Kabupaten Magelang”. Hasil penelitian tersebut menunjukkan bahwa peran OSIS dalam membentuk karakter siswa diantaranya adalah sebagai wadah yaitu tempat bagi siswa saling bekerja sama untuk mencapai tujuan, sebagai penggerak yaitu untuk membantu sekolah menjalankan kegiatan tertentu, dan sebagai sarana menghindarkan siswa untuk berbuat menyimpang dengan mengikuti kegiatan OSIS. Hampir sama yang ditunjukkan pada hasil penelitian ini bahwa OSIS SMA Negeri 3 Barru memiliki peran dengan membuat dan melaksanakan program kerja berbasis kegiatan sosial, menggerakkan atau memotivasi siswa pada kegiatan sosial, dan mencegah terjadinya penyimpangan di sekolah.

\section{Hambatan OSIS dalam Membentuk Karakter Peduli Sosial Siswa di SMA Negeri 3 Barru}

Pada bagian ini akan dibahas mengenai hambatan OSIS dalam membentuk karakter peduli sosial di SMA Negeri 3 Barru. Semua hal-hal yang menghambat atau bahkan menghalangi OSIS dalam membentuk karakter akan dibahas pada bagian ini. Setiap organisasi dalam menjalankan perannya pasti mengalami hambatan. Begitu pula dengan OSIS SMA Negeri 3 Barru yang mengalami kendala dalam membentuk karakter peduli sosial siswa.

Hal pertama yang menjadi hambatan OSIS SMA Negeri 3 Barru dalam membentuk karakter peduli sosial siswa adalah kurangnya kesadaran sosial siswa. Meskipun siswa di SMA Negeri 3 Barru memiliki siswa yang mayoritas memiliki kepekaan terhadap lingkungan sekitarnya, namun masih ada beberapa siswa yang masih kurang kesadaran akan hal tersebut. Pada saat melakukan penelitian penulis menemukan beberapa siswa yang kurang peduli terhadap teman kelasnya yang sedang mengikuti lomba Porseni. Mereka tidak memberikan dukungan kepada temannya yang sedang mengikuti lomba. Begitupun dengan panitia dari pengurus OSIS. Ada beberapa panitia yang kurang kerja sama pada saat Porseni sementara berlangsung. Padahal suksesnya kegiatan tergantung pada kerja sama dan kekompakan tim. Kurangnya kesadaran sosial siswa dapat dilihat dari sikap siswa yang cuek, malas, dan tidak peka dengan keadaan di sekelilingnya. 
Hasil penelitian menunjukkan bahwa salah satu penghambat OSIS dalam membentuk karakter peduli sosial siswa adalah masih ada beberapa siswa yang kurang kesadaran dengan lingkungan sekitarnya. Hal ini membuat OSIS merasa sedikit kesulitan karena sifat siswa yang sudah menjadi kebiasaan sulit untuk diubah.

Yang menjadi penghambat OSIS dalam pembentukan karakter peduli sosial siswa yang kedua adalah egoisme etis siswa. "Egoisme adalah tindakan dari setiap orang yang pada dasarnya bertujuan untuk mengejar kepentingan pribadi dan memajukan dirinya sendiri” (Qamar \& Salle, 2009, hal. 27). Sedangkan egoisme etis adalah tindakan yang mementingkan diri sendiri tanpa merugikan kepentingan orang lain. Sumber hambatan dalam mewujudkan kepedulian sosial terdapat dalam diri manusia sendiri yaitu egoisme, yang merupakan doktrin bahwa semua tindakan seseorang terarah atau harus terarah kepada diri sendiri. Orang yang memiliki sikap egois menutup diri agar tidak menaruh kepedulian kepada sesama.

Pada saat melakukan penelitian, penulis menemukan beberapa siswa yang masih memiliki sifat egois. Hal ini terlihat pada saat pengurus OSIS melakukan technical meeting untuk kegiatan Porseni. Ada beberapa siswa pada saat mengemukakan pendapat hanya mementingkan diri sendiri tanpa memperhatikan hasil rapat pengurus OSIS dengan pembina. Hal ini tentu menjadi penghambat OSIS dalam membentuk karakter siswa karena beberapa siswa belum mampu mengendalikan emosinya (Solehudin, 2018).

Hasil penelitian menunjukkan bahwa penghambat OSIS dalam pembentukan karakter peduli sosial siswa adalah adanya beberapa siswa yang masih memiliki sifat egois. Meski demikian, OSIS tetap berusaha untuk mendekati dan memberi pemahaman kepada siswa tersebut.

Yang menjadi penghambat OSIS dalam pembentukan karakter siswa yang ketiga adalah lingkungan luar. Lingkungan luar yang dimaksud adalah lingkungan luar sekolah. Hal ini bisa terjadi karena waktu siswa di sekolah hanya beberapa jam yang dilakukan untuk belajar dan membentuk karakter siswa. Selebihnya berada diluar lingkungan sekolah sehingga pengaruhnya juga sangat besar.

Lingkungan luar ini berupa teman bermain, keluarga, dan masyarakat. Siswa yang bergaul dengan teman dan masyarakat yang bisa memberikan pengaruh buruk pada siswa tersebut, maka sejatinya siswa tersebut akan mudah terpengaruh dan membawa kebiasaan buruk ke sekolah. Keluarga pun juga turut memberi pengaruh kepada siswa. Jika di rumah siswa diajarkan kebiasaan yang baik, maka karakter yang terbentuk juga akan baik.

Hasil penelitian menunjukkan bahwa lingkungan luar sekolah menjadi salah satu faktor penghambat dalam membentuk karakter peduli sosial siswa. Hal ini bisa terjadi karena waktu siswa untuk bersosialisasi lebih banyak terjadi di luar lingkungan sekolah.

Penghambat OSIS dalam membentuk karakter siswa yang keempat adalah kondisi ekonomi siswa. Kondisi ekonomi siswa yang tergolong dibawah menjadi salah satu penghambat dalam membentuk karakter peduli sosial siswa. Kepedulian siswa 
dapat dilihat ketika melihat teman atau orang yang berada disekitarnya membutuhkan bantuan dan siap untuk membantunya. Hal ini sesuai yang dikatakan pembina OSIS bapak Kaso Mustamin, S.Pd., M.Pd., bahwa "Sejauh ini kayaknya siswa kita kalau dilihat dari segi kemauan, kemauan ada. Paling karna mungkin juga disini ekonomi mereka banyak yang dibawah, itu saja kan.” (Hasil wawancara, 10 Desember 2019). Hal yang sama juga diungkapkan oleh kepala sekolah bapak Drs. H. Muhammad Abidin, M.Pd., bahwa yang bisa menjadi penghambat dalam pembentukan karakter peduli sosial siswa adalah kondisi ekonomi siswa. Dilihat dari pendapat informan diatas, kondisi ekonomi siswa yang tergolong dibawah tidak menjadi suatu kendala yang berarti sebab untuk membentuk karakter peduli sosial tidak harus dengan materi (Sanjaya, 2015).

Salah satu teori yang digunakan dalam penelitian ini yaitu teori struktural fungsional menggunakan konsep teori AGIL bahwa suatu sistem dapat bertahan apabila elemen-elemen dalam sistem tersebut menjalankan fungsinya masing-masing (Rafiqah, 2018). Jika dikaitkan dengan penelitian ini, sekolah sebagai suatu sistem dan bagianbagian sekolah seperti kepala sekolah, guru, staf tata usaha, organisasi siswa, dan siswa memiliki tugas dan fungsi yang saling berkaitan untuk mencapai tujuan bersama. Dari pembahasan diatas dapat dilihat bahwa OSIS masih memiliki hambatan dalam membentuk karakter peduli sosial siswa. Hal ini bisa terjadi jika beberapa elemen tadi ada yang tidak berjalan sebagaimana mestinya. Dari hasil penelitian ini pula ditemukan beberapa hambatan OSIS dalam membentuk karakter peduli sosial siswa diantaranya kurangnya kesadaran sosial siswa, egoisme etis siswa, lingkungan luar sekolah, dan kondisi ekonomi siswa.

Kemudian hasil penelitian yang dilakukan oleh Nursanti (2013, hlm vii) dengan judul "Peranan Organisasi Siswa Intra Sekolah dalam membentuk karakter siswa SMP Negeri di kabupaten Magelang" menunjukkan bahwa hambatan OSIS dalam membentuk karakter siswa adalah munculnya pelanggaran yang dilakukan oleh pengurus OSIS sendiri dan sebagian pengurus OSIS mengeluh karena sering tertinggal pelajaran di kelas. Hal berbeda yang ditunjukkan oleh hasil penelitian ini bahwa hambatan OSIS dalam membentuk karakter peduli sosial siswa adalah kurangnya kesadaran sosial siswa, egoisme etis siswa, lingkungan luar sekolah, dan kondisi ekonomi siswa.

\section{PENUTUP}

Berdasarkan hasil penelitian yang dilakukan di SMA Negeri 3 Barru maka penulis menyajikan beberapa kesimpulan berdasarkan rumusan masalah yang diangkat pada penelitian ini, yaitu:

1. Peran OSIS dalam membentuk karakter peduli sosial siswa di SMA Negeri 3 Barru yaitu dengan membuat dan melaksanakan program kerja berbasis kegiatan sosial, menggerakkan atau memotivasi siswa pada kegiatan sosial, dan mencegah terjadinya penyimpangan di sekolah. 
2. Penghambat OSIS dalam membentuk karakter peduli sosial siswa di SMA Negeri 3 Barru adalah kurangnya kesadaran sosial siswa, egoisme etis siswa, lingkungan luar sekolah, dan kondisi ekonomi siswa.

\section{DAFTAR PUSTAKA}

Agustang, A. (2021). Filosofi Research Dalam Upaya Pengembangan Ilmu. OSF Preprints.

Akbar, H., Oruh, S., \& Agustang, A. (2021). Indeks Prediktif Kejadian Demam Berdarah Dengue (DBD) Berbasis Perilaku Sosial Masyarakat Di Kabupaten Indramayu. Jurnal Kesehatan, 14(2 SE-), 76-82. https://doi.org/10.32763/juke.v14i2.289

Arpin, Agustang, A., \& Idkhan, A. M. (2021). Pengaruh Penerapan Model Dicovery Learning Terhadap Hasil Belajar Siswa Pada Mata Pelajaran IPA SD Inpres Tamalanrea V Kota Makassar. Journal Governance and Politics (JGP), 1(2 SEArticles). https://e-journal.iyb.ac.id/index.php/jgp/article/view/204

Arikunto, S. (2010). Metode peneltian. Jakarta: Rineka Cipta. Pembinaan Kesiswaan, Pub. L. No. 39 (2008).

Masni, M., Oruh, S., \& Agustang, A. (2021). Tinjauan Sosiologis Penanganan Kasus Kekerasan Dalam Rumah Tangga Menurut UU PKDRT Oleh Pengadilan Negeri Pangkep. Jurnal Sosialisasi: Jurnal Hasil Pemikiran, Penelitian Dan Pengembangan Keilmuan Sosiologi Pendidikan, 8, 108-117

Ningsih, T. (2015). Implementasi Pendidikan Karakter (A. W. B.S. \& A. Hidayat (eds.)). STAIN Press.

Nurlailah, N., \& Awaru, A. O. T. (2018). Strategi Guru Dalam Pembentukan Karakter Siswa Di Sma Negeri 1 Bissappu Kabupaten Bantaeng. Jurnal Sosialisasi: Jurnal Hasil Pemikiran, Penelitian Dan Pengembangan Keilmuan Sosiologi Pendidikan, 102-107.

Nursanti, D. (2013). Peranan Organisasi Siswa Intra Sekolah dalam membentuk karakter siswa SMP Negeri di Kabupaten Magelang. UNY.

Qamar, N., \& Salle. (2009). Etika dan Moral Profesi Hukum. CV. Social Politic Genius.

Ramlafatma, R., Oruh, S., \& Agustang, A. (2021). Efektivitas Pendidikan Moral Dalam Pembentukan Karakter Siswa Di TK Islam Terpadu Asa Sumbawa. Jurnal Ilmiah Mandala Education, 7(4).

Rafiqah, L. (2018). Pendekatan Struktural Fungsional terhadap Hukum Islam di Indonesia. Jurnal Al Himayah, 2(2), 205-216.

Rohmah, N. (2018). Integrasi kecerdasan intelektual (IQ), kecerdasan emosi (EQ) dan kecerdasan spiritual (SQ) dalam meningkatkan etos kerja. Tarbiyatuna: Jurnal Pendidikan Ilmiah, 3(2), 77-102.

Rosita, L. (2018). Peran pendidikan berbasis karakter dalam pencapaian tujuan pembelajaran di sekolah. JIPSI-Jurnal Ilmu Politik Dan Komunikasi UNIKOM, 8.

Sanjaya, W. (2015). Perencanaan dan desain sistem pembelajaran. Kencana. Solehudin, M. (2018). Peran Guru Pai Dalam Mengembangkan Kecerdasan

Emosional (EQ) dan kecerdasan spiritual (SQ) Siswa Smk KomputamaMajenang. Jurnal Tawadhu, 2(1), 303-325.

Supriatna, M. (2010). Pendidikan Karakter Melalui Ekstrakurikuler. UniversitasNegeri Bandung.

Tutuk, N. (2015). Implementasi pendidikan karakter.

Yaumi, M. (2014). Landasan, Pilar, dan Implementasi. Kencana Prenada media. 